\title{
PERAN ORANGTUA DALAM PENANAMAN TANGGUNGJAWAB PADA SISWA SD MUHAMMADIYAH AMBARKETAWANG 2 GAMPING
}

\author{
Nurmasita \\ Nurul Hidayati Rofiah \\ PGSD FKIP Universitas Ahmad Dahlan \\ nurmasita26@gmail.com
}

\begin{abstract}
Based on the results of observations and interviews to classroom teachers conducted by researchers there are still students who are less focused in listening to the ongoing learning process, there are children who, when given an individual task by the teacher who then asked for answers to his friends, often students do the task no maximum and if given the task of the house did not complete. This research aims to Describe the role of parents in planting responsibilities, and describe the factors that support and hinder the cultivation of responsibility to students.

The type of research is descriptive qualitative research type, with observation and interview data collection techniques while data analysis techniques using data reduction, presentation of data and conclusions and while the validity of the data used is triangulation techniques and triangulation of sources. The result of the research is the role of parents in the planting of responsibilities on the students of SD Muhammadiyah Ambarketawang 2 Gamping has implemented a good planting system in the form of motivation or support, meet the needs of children ranging from clothing, food and student boards, and be a mediator of children both in the scope of school and space the scope of the house and the contributing factors to the planting of responsibilities to the students is that there are some parents and who assume the character of responsibility is very important for the child by applying the punishment to the child if the child does not respond to the advice or motivation of the parents or teachers, and the assignment to the students is also applied by the teacher during the learning process takes place, and the inhibiting factor on planting the character of responsibility is the busyness of the working parents so that the time given to the child is slightly reduced
\end{abstract}

Keywords: Attention Deficit Hyperactivity Disorder (ADHD) Behavior in Learning Process

\begin{abstract}
ABSTRAK
Berdasarkan hasil dari observasi dan wawancara kepada guru kelas yang dilakukan oleh peneliti masih terdapat siswa yang kurang fokus dalam menyimak proses pembelajaran, terdapat anak apabila diberikan tugas individu oleh guru yang kemudian meminta jawaban kepada temannya, seringkali siswa mengerjakan tugas tidak maksimal dan tidak menyelesaikan pekerjaan rumah. Penelitian ini bertujuan untuk Mendeskripsikan
\end{abstract}


peran orangtua dalam penanaman tanggungjawab, dan mendeskripsikan faktor-faktor yang mendukung dan menghambat penanaman tanggung jawab pada siswa.

Jenis penelitian yaitu jenis penelitian deskriptif kualitatif, dengan teknik pengumpulan data observasi dan wawancara sedangkan teknik analisis data menggunakan reduksi data, penyajian data dan kesimpulan dan sedangkan keabsahan data yang digunakan adalah Triangulasi teknik dan triangulasi sumber. Hasil penelitian adalah peran orangtua dalam penanaman tanggungjawab pada siswa SD Muhammadiyah Ambarketawang 2 Gamping sudah menerapkan sistem penanaman cukup baik berupa pemberian motivasi atau dukungan, memenuhi kebutuhan anak mulai dari sandang, pangan dan papan siswa, dan menjadi mediator anak baik dalam ruang lingkup sekolah maupun ruang lingkup rumah dan Faktor pendukung pada penanaman tanggung jawab kepada siswa adalah terdapat beberapa orang tua dan yang mengganggap karakter tanggungjawab sangat penting untuk anak dengan menerapkan pemberian hukuman kepada anak apabila anak tidak merespon nasihat atau motivasi orang tua maupun guru, dan pemberian tugas kepada siswa juga diterapkan oleh guru pada saat proses pembelajaran berlangsung, dan Faktor penghambat pada penanaman karakter tanggungjawab adalah kesibukan orang tua bekerja sehingga waktu yang diberikan kepada anak sedikit berkurang

Kata kunci: Peran Orangtua, Penanaman Tanggung Jawab, Deskriptif Kualitatif.

\section{PENDAHULUAN}

Pendidikan yang mengembangkan karakter adalah bentuk pendidikan yang bisa membantu mengembangkan sikap etika, moral dan tanggungjawab memberikan kasih sayang kepada peserta didik dengan menunjukkan dan mengajarkan karakter yang bagus. Karakter yang harus ditanamkan kepada peserta didik diantaranya adalah cinta kepada Allah dan alam semesta berserta isinya, tanggungjawab, disiplin dan mandiri, jujur, hormat dan santun, kasih sayang, peduli dan kerja sama, percaya diri dan kreatif, kerja keras dan patang menyerah, keadilan dan kepemimpinan, baik dan rendah hati, toleransi, cinta damai dan persatuan.

Berdasarkan hasil observasi dan wawancara yang dilakukan oleh peneliti di SD Muhammadiyah Ambarketawang 2 Gamping, peneliti menemukan berbagai permasalahan, khususnya pada permasalahan peran orangtua terhadap perkembangan pendidikan karakter tanggungjawab anak. Sedangkan menurut Singgih (2008), masa anak sekolah ialah usia 612 tahun dianggap masa tenang atau masa talent dimana apa yang telah terjadi yang dipupuk pada masa sebelumnya akan berlangsung terus untuk masa-masa selanjutnya. Tahap usia ini disebut juga sebagai usia kelompok dimana anak mulai mengalihkan perhatian dan komunikasi baik dalam keluarga ke kerja sama antarteman dan sikap-sikap terhadap kerja atau belajar. Memasuki masa sekolah dasar salah satu hal penting yang perlu dimiliki anak adalah kematangan sekolah, tidak saja meliputi kecerdasan dan keterampilan motorik dan bahasa tetapi juga hal lain di luar orangtuanya, kesadaran akan tugas, patuh peraturan dan dapat mengendalikan emosinya. Pada fase ini anak mengalami lebih banyak tuntutan baik dalam masyarakat maupun dirinya sendiri. Yusuf (2016) berpendapat peranan orangtua pada pendidikan karakter siswa begitu penting dalam kehidupan sosial anak, karena pada fase ini kemampuan mengontrol emosi diperoleh anak 
melalui peniruan dan latihan (pembiasaan). Dalam proses peniruan, kemampuan orangtua dalam mengendalikan emosinya sangatlah berpengaruh. Orangtua seharusnya menjadi peranan penting dalam keluarga baik sebagai motivator maupun fasilitator yang artinya orangtua harus senantiasa memberikan motivasi/dorongan terhadap tumbuh kembang baik pendidikan maupun moral anaknya dan memenuhi kebutuhan anak baik sandang, pangan, dan papan. Selain harus memenihi kebutuhan sandang, pangan dan papan, orangtua juga harus memberikan kasih sayang, perhatian, dorongan, dan kehadiran orangtua disisinya (Sawani, 2017)

Permasalahan yang terjadi pada sekarang ini ialah kurangnya perhatian orangtua terhadap anaknya karena keduanya sama-sama bekerja. Kurangnya perhatian dari orangtua akan mengakibatkan anak mencari perhatian dari luar, baik di lingkungan sekolah dengan teman sebaya maupun dengan orangtua pada saat di rumah. Kesibukan orangtua juga mempengaruhi tingkat perkembangan pendidikan karakter siswa SD Muhammadiyah Ambarketawang 2 Gamping, dari hasil wawancara yang dilakukan oleh peneliti kepada guru kelas dan kepala sekolah mayoritas pekerjaan sehari-hari orangtua siswa ialah buruh bangunan dan pemuluh sehingga jam kerja mereka dimulai dari pagi pukul 06.00 hingga 18.00 jadi waktu yang digunakan orangtua bersama anak nya sangat singkat baik sebagai fasilitator maupun mediator.

Perkembangan moral seorang anak banyak dipengaruhi oleh lingkungannya. Anak memperoleh nilai-nilai moral dari lingkungannya, terutama dari orangtuanya. Dia belajar untuk mengenal nilai-nilai dan berperilaku sesuai dengan nilai-nilai tersebut. Sikap konsisten orangtua dalam menerapkan norma ialah apabila orangtua mengajarkan anak agar berperilaku jujur, bertutur kata yang sopan bertanggungjawab atau atau taat beragama, tetapi orangtua sendiri menampilkan perilaku yang sebaliknya, maka anak akan mengalami konflik pada dirinya dan akan menggunakan ketidak konsisitenan orangtua itu sebagai alasan untuk tidak melakukan apa yang diinginkan oleh orangtuanya, bahkan mungkin dia akan berperilaku seperti orangtuanya, (Yusuf, 2015)

Permasalahan yang terdapat di SD Muhammadiyah Ambarketawang 2 Gamping yaitu tentang moral anak tidak hanya permasalahan yang berkaitan tanggungjawab, pada observasi dan wawancara kepada guru kelas yang dilakukan oleh peneliti pada saat proses pembelajaran masih terdapat siswa yang kurang fokus dalam menyimak proses pembelajaran yang sedang berlangsung, terdapat anak yang apabila diberikan tugas individu oleh guru yang kemudian meminta jawaban kepada temannya, sopan santu yang dimiliki oleh siswa juga kurang seperti seringnya berbicara keras/kasar, seringkali siswa mengerjakan tugas yang diberikan oleh guru dengan tidak maksimal, terdapat juga anak yang sering menggangu teman sekelah pada proses pembelajaran berlangsung, dan terdapat juga anak yang apabila diberikan tugas rumah tidak menyelesaikan dan bahkan tidak menyelesaikan dengan baik. Rasa tanggungjawab baik terhadap diri sendiri maupun orang lain perlu ditanamkan pada siswa, karena hal tersebut membantu anak agar mengetahui setiap kesalahan perlu adanya pertanggungjawaban baik bagi diri sendiri maupun orang lain. Pada observasi dan wawancara yang peneliti lakukan di SD Muhammadiyah Ambarketawang 2 Gamping, terdapat juga siswa yang memiliki sifat rasa cemburu terhadap lawan jenis yang tidak semestinya dirasakan oleh anak usia sekolah dasar.

Berdasarkan hasil wawancara peneliti dengan guru di SD Muhammadiyah Ambarketawang 2 Gamping terdapat beberapa siswa yang memiliki orangtua yang telah bercerai atau tidak bersama-sama lagi sebagai sepasang suami istri dan dengan adanya hal ini membuat mereka harus memilih atau dipilih untuk tinggal bersama dengan ibu ataupun 
ayah mereka, sedangkan menurut Wahab (2008), peranan penting dimainkan oleh orangtua yang terdiri dari ibu dan ayah dalam ruang lingkup keluarga. Peran ibu dan ayah ini merupakan hal yang sangat diperlukan oleh pertumbuhan dan perkembangan peserta didik agar dapat memperoleh pendidikan baik sosial, budaya maupun moral anak. Kehadiran ibu dan ayah sangat mempengaruhi kemampuan fisik, emosi, sosial, intuisi, dan kognitif anak.

Pendidikan adalah bimbingan atau pimpinan yang dilakukan secara sadar oleh si pendidik terhadap perkembangan jasmani dan rohani si terdidik menuju terbentuknya kepribadian yang utama (Wibowo, 2012). Menurut Suyanto (Wibowo, 2012), karakter adalah cara berfikir dan berperilaku yang menjadi cirri khas tiap individu untuk hidup dan bekerja sam, baik dalam lingkup keluarga, masyarakat, bangsa dan negara. Jadi, penanaman karakter adalah peran dimana orangtua berperan penting dan berpartisipasi dalam perkembangan karakter siswa baik dalam ruang lingkup keluarga, tempat bermain dan sekolah.

Menurut Pusat Kurikulum (Suparlan, 2012) terdapat 18 pilar nilai-nilai karakter yang harus dikembangkan untuk anak didik di Indonesia. Ke-18 nilai beserta deskripsi untuk masing-masing nilai dapat dijelaskan sebagai berikut : 1) Religius, 2) Jujur, 3) Toleransi, 4) Disiplin, 5) Kerja Keras, 6) Kreatif, 7) Mandiri, 8) Demokrasi, 9) Rasa ingin tahu, 10) Semangat Kebangsaan, 11) Cinta Tanah Air, 12) Menghargai Prestasi, 13) Bersahabat/Komunikatif, 14) Cinta Damai, 15) Gemar Membaca, 16) Peduli Lingkungan, 17) Peduli Sosial, dan 18) Tanggungjawab.

Menurut Character Education Partnership (Suparlan, 2012) ada sebelas prinsip yang harus mendapatkan perhatian untuk melaksanakan pendidikan karakter pada satuan pendidikan, yaitu: (1) Pendidikan karakter harus dapat meningkatkan nilai-nilai etika teras dan mendukung nilai-nilai kinerja sebagai fondasi karakter yang baik. (2) Pendidikan karakter harus menetapkan karakter secara komprehensif, untuk memasukkan pemikiran, perasaan, dan perilaku. (3) Pendidikan karakter harus dilakukan dengan menggunakn satu pendekatan yang komprehensif, intensional, dan proaktif, untuk mengambangkan karakter. (4) Pendidikan karakter harus dapat menciptakan satu komunitas sekolah yang peduli. (5) Pendidikan karakter harus dapat menyediakan siswa dengan kesempatan untuk melakukan aksi-aksi atau kegiatan-kegiatan praktik tentang moral. (6) Pendidikan karakter harus dapat memasukkan satu kurikulum akademik yang bermakna dan menantang untuk menghargai semua pembelajar, mengembangkan karakternya, dan membantunya untuk berjaya. (7) Pendidikan karakter harus mengupayakan untuk mendorong motivasi diri pada diri siswa. (8) Pendidikan karakter harus memperlakukan staf sekolah sebagai komunitas moral dan pembelajaran yang berbagi tanggungjawab untuk pendidikan karakter dan mengupayakan untuk menyatukan pada nilai-nilai teras yang memandu pendidikan siswa. (9) Pendidikan karakter harus mampu mendorong kepemimpinan moral secara bersama dan dalam jangka panjang mendukung gagasan pendidikan karakter. (10) Pendidikan karakter harus mampu melibatkan keluarga dan warga masyarakat sebagai patner dalam upaya pembangunan karakter. (11) Pendidikan karakter harus dilaksanakan denagn melakukan peilaian terhadap karakter sekolah, pelaksanaan fungsi-fungsi staf sekolah, sebagai pendidik karakter, dan lebih dari itu sejauh mana siswa dalam menerapkan karakter yang baik.

Secara akademik, pendidikan karakter dapat dimaknai sebagai pendidikan nilai (value educatin), pendidikan budi pekerti, pendidikan moral (moral education), pendidikan watak, yang bertujuan untuk mengambangkan kemampuan peserta didik agar peserta didik dapat memberikan keputusan baik-buruk, memelihara apa yang baik itu, dan mewujudkan kebaikan itu dalam kehidupan sehari-hari denagn sepenuh hati. (Suparlan, 2012) Tujuan pendidikan karakter adalah: 1) mengembangkan potensi kalbu/nurani/afektif peserta didik sebagai manusia dan warganegara yang memiliki nilai-nilai karakter bangsa; 2) 
mengembangkan kebiasaan dan perilaku peserta didik yang terpuji dan sejalan dengan nilai-nilai universal dan tradisi budaya bangsa yang religius; 3) menanamkan jiwa kepemimpinan dan tanggungjawab peserta didik sebagai generasi penerus bangsa; 4) mengembangkan kemampuan peserta didik menjadi manusia yang mandiri, kreatif, berwawasan kebangsaan; dan 5) mengembangkan lingkungan kehidupan sekolah sebagai lingkungan belajar yang aman, jujur, penuh kreativitas dan persahabatan, serta dengan rasa kebangsaan yang tinggi dan penuh kekuatan (Judiani Sri 2010).

Karakter yang baik merupakan kunci terhadap rasa hormat atas diri sendiri, terhadap pemerolehan rasa hormat dari orang lain, terhadap hubungan positif, terhadap pernikahan yang bahagia, terhadap keberhasilan di setiap area kehidupan. Ketika kita mengajarkan sasaran kehidupan ini, yang semuanaya memerlukan pengarahan kepada kehidupan yang baik, kita sedang menjalani hidup sesuai dengan diri kita yang paling dalam. Ketika kita mengabaikan atau bertentangan dengan sasaran ini menunjukkan karakter yang buruk, bertindak tanpa rasa ibadalam hubungan kita, mengambil dari orang lain tanpa kontribusi terhadap kebaikan mereka. (Lickona, 2012). berikut cara membesarkan anak berkarakter menurut (Lickona, 2012:) : (1) jadikan pengembangan karakter sebagai prioritas utama. (2) jadilah orangtua yang otoriter. (3) cinta anak-anak. (4) mengajar dengan contoh. (5) mengelola lingkungan moral. (6) gunakan pengajaran langsung untuk membentuk hati nurani dan kebiasaan. (7) mengajarkan keputusan yang baik. (8) memecahkan masalah dengan adil. (9) memberikan kesempatan untuk mempraktikkan kebijakan. (9) mendorong pengembangan spiritual.

Tanggungjawab merupakan suatu bentuk lanjutan dari rasa hormat. Jika sudah menghormati orang lain, berarti kita menghargai mereka. Jika kita menghargai mereka, berarti kita merasakan sebuah ukuran dari rasa tanggungjawab karena untuk menghormati kesejahteraan hidup mereka. Tanggungjawab, secara liberal berarti "kemampuan untuk merespon atau menjawab". Itu artinya, tanggungjawab berorientasi terhadap orang lain memberikan bertuk perhatian, dan secara aktif memberikan respons terhadap apa yang meraka inginkan. Tanggungjawab menekankan pada kewajiban positif untuk saling melindungi satu sama lain. (Lickona, 2012:72). Menurut (Lickona, 2012:258) terdapat 4 tingkat atau level pada tanggungjawab. yaitu : (1) Level 4, pada level ini orang lebih cendrung memiliki sikap dan perilaku Penuh rasa hormat, penuh rasa tanggungjawab, membantu orang lain. Karakteristik dari level ini adalah seluruh kakarteristik. (2) level 3, ditambah melakukan apa yang ditugaskan dan lebih, memberikan bantuan apabila ada kesempatan, memiliki kreativitas melebihi yang diharapakan. (3) Level 2, pada level ini orang lebih cendrung memiliki sikap dan perilaku penuh rasa hormat, dan penuh tanggungjawab. Karakteristik dari level ini adalah pekerja keras, melekukan apa yang diharapkan, menghormati hak-hak dan pekerjaan orang lain, menyelesaikan pekerjaan dengan hati-hati, menggunakan waktu dengan baik, menggunakan materi dengan hati-hati dan bertanggungjawab, melakukan pembicaraan dengan baik dan bertekun. (4) Level 2, pada level ini orang lebih cendrung memiliki sikap dan perilaku bekerja ketika diingatkan. Karakteristik dari level ini adalah pekerjaan diselesaikan dengan pengingat atau pertanyaan yang diberikan oelh orang dewasa yang hadir, tidak banyak pekerjaan yang terlihat, melakukan pembicaraan yang tidak baik, mungkin ceroboh, kadang-kadang bekerja dan kadang-kadang tidak bekerja. (5) Level 1, Pada level ini orang lebih cendrung memiliki sikap dan perilaku tidak bekerja. Karakteristik pada level ini adalah sangat sedikit atau tidak ada pekerjaan yang terlihat sama sekali di akhir waktu yang diberikan, berputarputar, dan bingung. (6) Level 0, Pada level ini orang lebih cendrung memiliki sikap dan perilaku menggangu orang lain. Karakteristik pada level ini adalah berbicara dengan keras, seringkali ceroboh atau bodoh, pekerjaan yang dicapai jumlahnya minimal atau 
diselesaikan dengan ceroboh, tindakannya mencampuri kemampuan anak lain untuk berkonsentrasi, menyalahgunakan materi.

Pengertian peran orangtua yang dimaksud dalam penelitian ini adalah orangtua sebagai motivator, dan fasilitator. Sebagai motivator, orangtua harus senantiasa memberikan motivasi/dorongan terhadap anaknya untuk berbuat kebajikan dan meninggalkan larangan Tuhan. Orangtua sebagai fasilitator artinya adalah orangtua harus memberikan fasilitas, pemenuhan kebutuhan keluarga/anak berupa sandang, pangan, dan papan termasuk kebutuhan pendidikan. Orangtua sebagai motivator ialah selain pemenuhan kebutuhan material, anak juga perlu diberikan kasih sayang, perhatian, dorongan, dan kehadiran orangtua disisinya, dan selanjutnya orangtua sebagai mediator adalah adanya keterlibatan orangtua terhadap tumbuh kembang anak (Sawani, 2017).

Para ahli berpendapat bahwa peranan orangtua begitu besar dalam membantu anak agar siap memasuki gerbang kehidupan mereka. Ketika memasuki gerbang tersebut, mereka masuk dalam dunia independen yang sudah seharusnya terlepas dari orangtua, dimana keputusan hidup mereka sudah harus dapat dilakukan sendiri. Disinilah peran orangtua sudah berkurang, dan melihat hasil didikan mereka. Maka perlu adanya partisipasi orangtua terhadap pendidikan anak usia dini agar anak memiliki kesiapan dalam memasuki gerbang kehidupan tersebut.

\section{METODE PENELITIAN}

Jenis penelitian ini adalah penelitian deskriptif kualitatif. Dalam penelitian ini peneliti mendeskripsikan peran orangtua dalam menanamkan karakter tanggungjawab siswa SD Muhammadiyah Ambarketawang 2 Gamping. Tempat penelitian yang digunakan dalam penelitian ini adalah di SD Muhammadiyah Ambarketawang 2 Gamping. Waktu yang digunakan dalam penelitian ini adalah pada bulan juni 2017. Pada penelitian ini objek penelitian adalah peran orangtua terhadap penanaman karakter tanggungjawab siswa SD Muhammadiyah Ambarketawang 2 Gamping.

Teknik Pengumpulan Data menggunakan observasi, wawancara (kepala sekolah, guru, orangtua). Proses dalam teknik pengumpulan data menggunakan pedoman wawancara yang ditujukan kepada Wakil Kepala Sekolah, Guru, Orangtua, dan siswa untuk mengetahui informasi terkait dengan proses penanaman karakter kepada wakil kepala sekolah dan guru kelas yang berperan dalam pelaksanaan pendidikan karakter. Teknik keabsahan data dilaksanakan dengan triangulasi. Menurut Putra (2011) dalam bahasa sehati-hari, triangulasi denagn istilah cek dan ricek yaitu pengecekan data menggunakan beragam sumber, teknik, dan waktu.adapun penelitian ini menggunakan triangulasi teknik dan sumber. Teknik analisis data pada penelitian ini menggunakan teknik observasi dan wawancara. Data kualitatif digunakan untuk mendeskripsikan hasil wawancara sebelum tindakan dan sesudah tindakan maupun penelitian yang dilakukan kedalam bentuk kalimat. Adapun analisis data yang dilakukan menurut (Sugiono, 201:89) sebagai berikut: 1) Reduksi Data (Data Reduction), 2) Penyajian Data (Data Display), 3) Conclusioon Drawing (Kesimpulan). 


\section{HASIL DAN PEMBAHASAN}

\section{A. Hasil Penelitian}

1. Peran orangtua dalam penanaman karakter tanggungjawab siswa SD Muhammadiyah Ambarketawang 2 Gamping. Sesuai dengan hasil penelitian yang telah diperoleh peneliti dari informan, berikut ini dikemukakan data temuan di lapangan diperoleh dari wawacara, observasi, dan dokumentasi. Adapun data yang diperoleh meliputi indikator keberhasilan peran orangtua sebagai Motivator, Fasilitator dan Mediator adalah sebagai berikut.

a) Motivator

Penelitian yang dilakukan oleh peneliti di SD Muhammadiyah Ambarketawang 2 Gamping diperoleh data terkait dengan peran orangtua terhadap karakter tanggungjawab dengan wawancara kepada orangtua sebagai motivator. Berikut data hasil wawancara kepada narasumber.

1) kebanyakan dari mereka memberikan motivasi pembelajaran kepada anak mereka pada jam di mana mereka tidak sedang bekerja dan anak sedang berada di rumah. Pada hasil wawancara yang dilakukan oleh peneliti kepada narasumber, peneliti menemukan hasil bahwa sebagai orangtua, motivasi tidak hanya diberikan untuk keperluan sekolah anak mereka, melainkan menanamkan karakter tanggungjawab perlu dengan memberikan tugas-tugas yang sudah bias anak mereka lakukan di usia tersebut.

2) Narasumber lain juga berpendapat bahwa mereka memotivasi anak mereka pada saat mereka tidak sedang sibuk bekerja. Pada hasil wawancara yang dilakukan oleh peneliti kepada narasumber, memberikan motivasi atau dorongan tidak hanya berupa ungkapan dan tingkah laku, memberikan anak waktu atau kesempatan untuk bermain agar tugas sekolah dan rumah tidak menjadi beban.

3) Penanaman karakter tanggungjawab anak tidak hanya pada proses pembelajaran di rumah saja, namun penanaman karakter tanggungjawab mandiri di rumah juga ditanamkan kepada anak untuk membantu pekerjaan anak di rumah. Pada hasil wawancara yang dilakukan oleh peneliti kepada narasumber, sebagai orangtua penanaman karakter tanggungjawab kepada anak tidak hanya mengandalkan dorongan dari kedua orangtua melainkan juga tingkat tingkat kepekaan anak terhadap lingkungan.

4) Karakter tanggungjawab tidak hanya perlu ditanamkan oleh oleh tua kepada anak pada saat pembelajaran atau kegiatan anak membantu orangtua dirumah, namun juga motivasi orangtua kepada anak tentang tanggungjawab diri sendiri kepada Tuhan Yang Maha Esa. Sebagai umat islam kewajiban salah satunya adalah sholat. Pada hasil wawancara yang dilakukan oleh peneliti kepada narasumber, sebagai orangtua penanaman karakter tanggungjawab kepada anak tidak hanya untuk diri anak sendiri melainkan kehidupan anak baik kepada diri sendiri maupun tugasnya kepada Tuhan Yang Maha Esa.

b) Fasilitator

Penelitian yang dilakukan oleh peneliti di SD Muhammadiyah Ambarketawang 2 Gamping diperoleh data terkait dengan peran orangtua 
terhadap karakter tanggungjawab dengan wawancara kepada orangtua sebagai fasilitator. Berikut data hasil wawancara kepada narasumber.

c) Faktor Pendukung

Faktor yang mendukung berhasilnya seorang menanamkan tanggungjawab kepada anak adalah dengan berupa pemberian tugas, pemberian hukuman dan kasih sayang kepada anak seperti yang diungkapkan oleh guru berikut ini.

1) Hasil wawancara yang dilakukan oleh peneliti kepada orangtua siswa sebagai fasilitator adalah sebagian besar dari orangtua siswa tidak melupakan kewajiban mereka sebagai orangtua dalam memberikan kebutuhan anak baik materi dan non materi. Pada hasil wawancara yang dilakukan oleh peneliti kepada narasumber, Peran orangtua sebagai Fasilitator adalah memenuhi kebutuhan anak, baik sandang, pangan dan papan. Hal tersebut sudah memenuhi kebutuhan anak dalam hal sandang, pangan dan papan.

2) Sebagai orangtua tidak hanya memenuhi kebutuhan sandang, pangan dan papan anak, tetapi juga selalu berada di samping anak agar anak merasa keberadaan orangtua mereka di samping mereka untuk tanggungjawab yang telah diberikan kepada siswa dengan memberikan hukuman berbertuk denda uang yang nantinya uang tersebut akan di masukkan ke dalam kas kelas. Pemberian hukuman berupa denda, peneliti temukan pada wawancara dan observasi kepada guru merupakan hal yang baik, hal tersebut dikarenakan dapat menumbuhkan rasa tanggungjawab siswa kepada diri seddiri dan juga menumbuhkan sikap menghargai orang lain.

3) Terdapat juga cara yang diberikan kepada siswa agar memiliki motivasi untuk lebih bertanggungjawab dengan memberikan hukuman membersihkan kelas apabila tanggungjawab tidak dikerjakan dengan optimal. Pemberian hukuman berupa tanggungjawab piket kelas juga dianggap baik untuk perkembangan karakter tanggungjawab siswa karena dengan adanya hal tersebut siswa dapat menghargai orang lain dan juga bertanggungjawab padadiri sendiri. Faktor pendukung lainnya perlu ditanamkan kepada siswa adalah peran orangtua dalam membantu menumbukan karakter tanggungjawab anak di rumah berikut ini.

4) Pemberian tugas di rumah salah satu faktor pendukung terbentuknya karakter tanggungjawab

5) Pemberian hukuman apabila siswa tidak melaksanakan tugas rumah juga dianggap efektif dalam membentuk karakter tanggungjawab anak. Faktor pendukung lainnya perlu ditanamkan kepada siswa adalah peran kepala sekolah dalam membantu menumbukan karakter tanggungjawab anak di ruang lingkup sekolah berikut ini.

6) Pemberian nasihat atau motivasi berbentuk kasih sayang dianggap efektif untuk menumbuhkan rasa tanggungjawab kepada siswa. 
d) Faktor Penghambat

1) Kesibukan orangtua dalam bekerja menjadi faktor penghambat penanaman karakter tanggungjawab di rumah.

2) Kurangnya nilai karakter religius yang menjadi faktor penghambat penanaman karakter tanggungjawab

\section{B. Pembahasan Penelitian}

1. Peran orangtua dalam penanaman karakter tanggungjawab

a. Motivator

Peran orangtua sebagai motivator adalah memberikan dorongan baik dalam lingkungan sosial, dan lingkungan keluarga anak yang diberikan oleh kedua orangtua. Hasil penelitian yang dilakukan oleh peneliti menggunakan teknik wawancara di SD Muhammadiyah Ambarketawang 2 Gamping menemukan kurangnya perhatian dikarenakan kesibukan orangtua dalam bekerja sehingga membuat anak kekurangan perhatian dan motivasi dalam penanaman karakter tanggungjawab.

a. Fasilitator

Pemenuhan kebutuhan mulai dari sandang, pangan dan papan sudah menjadi kewajiban orangtua, namum pemenuhan kebutuhan tidak hanya tentang sandang, pangan dan papan melainkan juga kesih sayang dan keberadaan orangtua dis sisi anak juga sangat diperlukan. Hasil wawancara dan observasi yang dilakukan oleh peneliti di SD Muhammadiyah Amabarketawang 2 Gamping menemukan kebanyak dari orangtua memprioritaskan kebutuhan siswa seperti kebutuhan dalam proses pembelajaran seperti pensil, pulpen, buku tulis dan buku paket siswa. Namun untuk kebutuhan non material orangtua masih belum sepenuhnya bias selalu berada di sisi anak pada saat proses pembelajaran maupun di rumah dikarenakan kesibukan orangtua bekerja.

b. Mediator

Hasil wawancara peneliti dengan orangtua terkait dengan peran orangtua dalam penanaman karakter tanggungjawab menemukan beberapa jawaban yang dikemukakan oleh narasumber. Kebanyakan dari narasumber yaitu orangtua berpendapat bahwa mereka sebagai orangtua telah menjadi pelengkap atau mediator dalam proses pembelajaran anak dan mengetahui tingkat perkembangan pembelajaran anak meraka di sekolah dan telah dengan baik mengajarkan tanggungjawab kepada anak.

Hal tersebut sesuai dengan peran orangtua sebagai mediator menurut Sawani (2017) beliau berpendapat peran orangtua sebagai mediator adalah adanya keterlibatan orangtua terhadap tumbuh kembang anak.

2. Faktor yang mendukung dan menghambat penanaman karakter tanggungjawab

a. Faktor Pendukung

Hasil wawancara yang dilakukan oleh peneliti di SD muhammadiyah Ambarketawang 2 Gamping menemukan beberapa faktor yang mendukung penanaman karakter tanggungjawab yaitu terdapat beberapa orangtua yang menganggap etika/karakter tanggungjawab perlu ditanamkan sejak dini melalui pemberian contoh dan motivasi/nasehat kepada anak, selain itu terdapat juga beberapa orangtua yang menerapkan sistem tegas dengan memberikan hukuman kepada anak agar memiliki efek jera terhadap anak. 
Selain peran pendukung dari orangtua, peran lainnya ditunjukkan oleh guru saat proses pembelajaran berlangsung, banyak cara yang diterapkan oleh guru untuk menanamkan karakter tanggungjawab pada saat proses pembelajaran seperti memberikan tugas harian kepada anak berupa buku tugas mulai dari bangun tidur hingga tidur kembali. Selain dengan pemberian tugas, memberi hukuman berupa denda dan membersihkan kelas juga diterapkan oleh beberapa guru untuk memberikan efek jera kepada anak.

b. Faktor Penghambat

Hasil wawancara yang dilakukan oleh peneliti di SD muhammadiyah Ambarketawang 2 Gamping menemukan beberapa faktor yang menghambat penanaman karakter tanggungjawab yaitu terdapat beberapa orangtua yang bekerja sebagai buruh, baik buruh jahit atau pun pedagang jadi waktu yang diluangkan untuk anak berkurang.

\section{KESIMPULAN}

Berdasarkan hasil penelitian dan pembahasan, maka penelitian ini dapat disimpulkan sebagai berikut: (1) peran orangtua dalam penanaman karakter tanggungjawab di SD Muhammadiyah Ambarketawang 2 Gamping sudah menerapkan sistem penanaman cukup baik berupa pemberian motivasi atau dukungan, memenuhi kebutuhan anak mulai dari sandang, pangan dan papan siswa, dan menjadi mediator anak baik dalam ruang lingkup sekolah maupun ruang lingkup rumah, (2) beberapa hambatan terkait dengan penanaman tanggungjawab juga terdapat pada siswa yang kurang merespon adanya motivasi baik dari orangtua, dan juga guru, (3) faktor pendukung pada penanaman karakter tanggungjawab kepada siswa adalah terdapat beberapa orangtua dan yang mengganggap karakter tanggungjawab sangat penting untuk anak dengan menerapkan pemberian hukuman kepada anak apabila anak tidak merespon nasihat atau motivasi orangtua maupun guru, dan pemberian tugas kepada siswa juga diterapkan oleh guru pada saat proses pembelajaran berlangsung, (4) faktor penghambat pada penanaman karakter tanggungjawab adalah kesibukan orangtua bekerja sehingga waktu yang diberikan kepada anak sedikit berkurang.

\section{DAFTAR PUSTAKA}

Arikunto, Suharsimi. 2013. Prosedur Penelitian Suatu Pendekatan Praktik. PT. Rineka Cipta, Jakarta

Judiani, Sri. 2010. "Implementasi Pendidikan Karakter di Sekolah Dasar Melalui Penguatan Pelaksanaan Kurikulum”. Jurnal. Pendidikan dan Kebudayaan, Vol. 16. jurnaldikbud.kemdikbud.go.id

Singgih, Gunarsa. 2008. Psikologi Perkembangan Anak dan Remaja. PT BPK Gunung Mulia Jakarta

Sugiyono. 2015. Metode Penelitian Pendidikan :Pendekatan Kuantitatif, Kualitatif, dan $R \& D$. Alfabeta, Bandung

Suparlan, 2012. Praktik-praktik Terbaik Pelaksanaan Pendidikan Karakter. Hikayat Publishing. Yogyakarta 
Wahab, Rohmat. 2008. Peranan Orangtua dan Pendidikan dalam Mengoptimalkan Potensi Anak Berbakat Akademik.

Lickona, Thomas. 2015. Character Matters (Bagaiamana Membantu Anak Mengembangkan Penilaian yang Baik, Integrasi, dan Kebijakan Penting lainnya). PT Bumi Aksara, Jakarta

Moleong, Lexy. 2007. Metodologi Penelitian Kualitatif. PT Remaja Rosdakarya, Bandung

Sawani, Intan. 2017. Peranan Orangtua dalam Mengembangkan Religiusitas Anak. Beutong, Kabupaten Nagan Raya Aceh 